\title{
KEMANDIRIAN BELAJAR MATEMATIKA SISWA DALAM PEMBELAJARAN KOOPERATIF DENGAN AKTIVITAS QUICK ON THE DRAW
}

\section{(MATHEMATICAL SELF REGULATED LEARNING OF STUDENTS IN COOPERATIVE LEARNING WITH QUICK ON THE DRAW ACTIVITY)}

\author{
Asri Nurhafsari ${ }^{1}$, Jozua Sabandar ${ }^{2}$ \\ ${ }^{1}$ Universitas Islam Syekh Yusuf Tangerang, ${ }^{2}$ Universitas Pendidikan Indonesia \\ email: anurhafsari@unis.ac.id
}

\begin{abstract}
Abstrak
Tujuan penelitian kuasi eksperimen ini adalah mengkaji kemandirian belajar matematika siswa yang belajar matematika melalui pembelajaran kooperatif dengan aktivitas quick on the draw dan siswa yang memperoleh pembelajaran biasa. Penelitian ini menggunakan desain eksperimen perbandingan kelompok statik. Populasi penelitian ini adalah seluruh siswa kelas VIII salah satu SMP Negeri di Kabupaten Tangerang. Pengambilan sampel dalam penelitian ini melalui teknik purposive sampling. Instrumen yang digunakan dalam penelitian ini adalah angket skala kemandirian belajar matematika. Hasil penelitian menunjukkan bahwa kemandirian belajar matematika siswa yang menggunakan pembelajaran kooperatif dengan aktivitas quick on the draw lebih baik secara signifikan daripada siswa yang memperoleh pembelajaran biasa.
\end{abstract}

Kata kunci: kemandirian belajar, pembelajaran kooperatif, quick on the draw

\begin{abstract}
The main purpose of this quasi-experimental research is to study mathematical self regulated learning of students who learn to use cooperative learning with quick on the draw activity and students who receive regular learning. The research is conducted by using a static group comparison design. The population of research is all students of class VIII in one of State Junior High Schools in Tangerang. The sampling of research by using a purposive sampling. The instruments used in this research is questionnaire to self regulated learning. The results of this research show that self regulated learning of students who learn to use cooperative learning with quick on the draw activity is better than the students who receive regular learning.
\end{abstract}

Keywords: self regulated learning, cooperative learning, quick on the draw 


\section{PENDAHULUAN}

Pendidikan dituntut untuk menghasilkan lulusan yang berkualitas agar mampu bersaing pada era globalisasi saat ini. Banyak upaya yang dilakukan pemerintah dengan membuat kebijakan- kebijakan terhadap dunia pendidikan, salah satunya dengan kebijakan mengenai kurikulum yang masih berkembang di pendidikan Indonesia.

Berubahnya kurikulum dari dahulu hingga saat ini tidak terlepas pada tujuan pendidikan nasional sebagai acuannya. Seperti yang tertuang dalam UU Nomor 20 tahun 2003 tentang Sistem Pendidikan Nasional, tujuan pendidikan nasional yaitu mengembangkan potensi peserta didik agar menjadi manusia yang beriman dan bertakwa kepada Tuhan Yang Maha Esa, berakhlak mulia, berilmu, cakap, kreatif, mandiri dan bertanggung jawab. Ditinjau dari tujuan pendidikan nasional tersebut, aspek mandiri merupakan salah satu kompetensi yang penting untuk dimiliki siswa. Apabila siswa memiliki kemandirian yang tinggi maka diharapkan ia akan mampu menghadapi tantangan zaman yang kompetitif dengan tidak bergantung pada orang lain.

Aspek kemandirian dalam belajar matematika juga merupakan hal yang penting, karena dalam belajar matematika siswa dituntut untuk lebih banyak berlatih secara mandiri agar dapat mengembangkan kompetensi matematikanya. Hal ini sejalan dengan pendapat Sumarmo (2013) yang mengemukakan bahwa untuk dapat suskses dalam pembelajaran matematika, setiap individu yang belajar matematika dituntut harus memiliki disposisi matematis yang tinggi, sehingga akan menghasilkan kemampuan matematis yang sesuai dengan harapan. Lebih lanjut lagi, Sumarmo mengemukakan bahwa kebiasaan dan sikap belajar siswa akan terlukis pada karakteristik kemandirian belajar matematika, yaitu: (1) menganalisis kebutuhan belajar matematika, merumuskan tujuan, dan merancang program belajar; (2) memilih dan menerapkan strategi belajar; (3) memantau dan mengevaluasi diri apakah strategi telah dilaksanakan dengan benar, memeriksa hasil (proses dan produk), serta merefleksi untuk memperoleh umpan balik.

Pentingnya kemandirian belajar dalam matematika ini didukung oleh hasil studi Hargis (Sumarmo, 2013) yang mengungkapkan bahwa individu yang memiliki kemandirian belajar yang tinggi akan cenderung belajar lebih baik, mampu memantau, mengevaluasi, dan mengatur belajarnya secara efektif; menghemat waktu dalam menyelesaikan tugasnya; mengatur belajar dan waktu secara efisien, dan memperoleh skor yang tinggi dalam sains. Jadi, dapat disimpulkan bahwa pengembangan kemandirian belajar sangat diperlukan oleh individu yang belajar matematika.

Akan tetapi permasalahan yang ada hingga saat ini adalah pembelajaran di kelas yang kurang optimal dalam menunjang kemandirian belajar siswa. Pembelajaran yang ada masih memusatkan guru sebagai satu-satunya sumber belajar sehingga belum memunculkan motivasi belajar yang tinggi bagi siswa. Siswa terlalu mengandalkan penjelasan materi dari guru dan sedikit sekali siswa yang berusaha mencari sumber-sumber belajar lain untuk menunjang tugas akademiknya. Pembelajaran yang seperti ini menyebabkan siswa cenderung pasif dalam pembelajaran, menerima apa saja yang diajarkan guru sehingga siswa tidak belajar mengkonstruksi pengetahuannya sendiri. Hal ini sejalan dengan pendapat Slettenhaar (Permana, 2010) menyatakan bahwa pada model pembelajaran sekarang ini, umumnya aktivitas siswa hanya mendengar dan menonton 
penjelasan guru, kemudian guru menyelesaikan sendiri dengan satu cara penyelesaian dan memberi soal latihan untuk diselesaikan sendiri oleh siswanya.

Melihat kondisi pembelajaran yang seperti ini, maka perlu adanya perubahan dalam proses pembelajaran. Pembelajaran yang dilaksanakan tidak lagi berpusat pada guru, melainkan berpusat pada siswa (student center learning), sehingga memberikan kesempatan siswa untuk aktif dalam pembelajaran. Siswa tidak lagi mengandalkan guru sebagai satu-satunya sumber belajar, tetapi ia harus mampu belajar secara mandiri sehingga dapat menunjang keberhasilan belajar matematika.

Oleh karena itu, untuk menumbuhkan sikap kemandirian belajar matematika siswa maka perlu diupayakan suatu pembelajaran matematika yang dapat menunjang kemandirian belajar siswa. Upaya yang dilakukan adalah dengan menggunakan model pembelajaran yang dapat mendorong siswa untuk belajar secara aktif dan mengkonstruksi pengetahuannya dari berbagai sumber belajar, serta menciptakan pembelajaran yang menggugah semangat dan motivasi tinggi siswa untuk belajar lebih mandiri.

Salah satu cara yang diduga dapat menumbuhkan kemandirian belajar siswa adalah dengan menerapkan pembelajaran kooperatif. Menurut Majid (2014) pembelajaran kooperatif merupakan bentuk pembelajaran dengan cara siswa belajar dan bekerja dalam kelompok-kelompok kecil yang heterogen. Pembelajaran ini lebih mengutamakan kerjasama untuk mencapai tujuan pembelajaran dan dapat membuat siswa aktif dalam pembelajaran. Agar lebih bervariasi dan dapat menumbuhkan semangat serta motivasi yang tinggi, maka pembelajaran kooperatif perlu dikombinasikan dengan suatu aktivitas yang mengandung tantangan tetapi menyenangkan, yaitu aktivitas quick on the draw. Aktivitas ini mempunyai kesesuaian dengan pembelajaran kooperatif karena merupakan suatu aktivitas kerjasama dalam tim. Kegiatan seperti ini dapat membantu siswa untuk membiasakan diri belajar pada sumber-sumber belajar lain bukan hanya pada guru, sehingga dapat melatih kemandirian belajar siswa dan terasa menyenangkan pembelajaran yang ada di kelas.

Berdasarkan uraian yang telah dipaparkan di atas maka peneliti terdorong untuk melaksanakan penelitian mengenai kemandirian belajar matematika siswa dalam pembelajaran kooperatif dengan aktivitas quick on the draw. Tujuan dilakukannya penelitian ini adalah untuk mengkaji kemandirian belajar matematika siswa yang menggunakan pembelajaran kooperatif dengan aktivitas quick on the draw dan siswa yang memperoleh pembelajaran biasa.

\section{KAJIAN TEORI}

\section{a. Kemandirian Belajar Matematika}

Proses pembelajaran yang baik hendaknya berprinsip "student centered learning" dimana siswa berperan sebagai pusat pembelajaran. Siswa tidak hanya duduk diam menerima penjelasan guru melainkan siswa didorong untuk berperan secara aktif sehingga ia mampu mengkonstruksi konsep dan pengetahuan berdasarkan data, informasi maupun pengetahuan yang dimiliki sebelumnya. Kondisi seperti inilah yang dapat mengarahkan siswa menjadi pribadi yang mandiri sehingga dapat memunculkan kemandirian belajar siswa.

Kemandirian belajar bukan merupakan kemampuan akademik maupun bakat yang memang dimiliki oleh setiap siswa. Akan tetapi, kemandirian belajar 
merupakan suatu siklus dari pengarahan diri secara berulang-ulang dan dapat diajarkan pada siswa. Kemandirian belajar juga merupakan faktor penting dari keadaan individu yang mempengaruhi siswa dalam belajar.

Schunk dan Zimmerman (Zamnah, 2012) mendefinisikan kemandirian belajar sebagai proses belajar yang terjadi karena pengaruh dari pemikiran, perasaan, strategi dan perilaku individu di dalam proses yang dijalani untuk mencapai tujuan belajar. Sedangkan Wolters, Pintrich, dan Karabenick (Hidayat, 2009) menegaskan bahwa kemandirian belajar adalah suatu proses konstruktif dan aktif dimana siswa menentukan tujuan dalam belajar, dan mencoba untuk memonitor, mengatur, dan mengendalikan kognisi, motivasi, dan perilaku dengan dibimbing dan dibatasi oleh tujuan dan karakteristik kontekstual dalam lingkungan.

Menurut Zumbrun, Tadlock, dan Robert (2011) kemandirian belajar adalah suatu proses yang membantu siswa dalam mengelola pikiran, perilaku, dan emosi agar mampu mengendalikan pengalaman belajar yang mereka alami sendiri. Selanjutnya menurut Sumarmo (2013) kemandirian belajar merupakan proses perancangan dan pemantauan diri yang seksama terhadap proses kognitif dan afektif dalam menyelesaikan suatu tugas akademik.

Lebih lanjut, Montalvo dan Torres (Hidayat, 2009) mengungkapkan bahwa kemandirian belajar merupakan gabungan antara keterampilan dan kemauan. Sejalan dengan pendapat tersebut, Darr dan Fisher (2004) mengungkapkan bahwa siswa yang mempunyai kemandirian belajar adalah siswa yang secara aktif terlibat dalam memaksimalkan kesempatan dan kemampuannya untuk belajar. Hal ini tidak hanya melibatkan aktivitas kognitif tetapi juga dapat mengembangkan keterampilan yang memungkinkan dalam pengaturan sikap, lingkungan, dan perilaku.

Berdasarkan beberapa pendapat para ahli diatas, dapat disimpulkan bahwa kemandirian belajar adalah suatu proses dimana siswa terlibat secara aktif untuk merancang tujuan, memilih strategi, memantau proses kognitif dan afektif dalam menyelesaikan suatu tugas akademik. Jadi, kemandirian belajar akan mengacu kepada cara yang siswa lakukan dalam mengontrol belajarnya.

Kemampuan individu dalam memaksimalkan kemandirian belajar bukan merupakan suatu bakat, namun dapat ditingkatkan melalui program belajar yang relevan. Sumarmo (2013) mengemukakan bahwa pada kemandirian belajar akan memuat kegiatan-kegiatan belajar yang meliputi mengevaluasi diri, mengatur dan mentransformasi, menetapkan tujuan dan rancangan, mencari informasi, mencatat dan memantau, menyusun lingkungan, mencari konsekuensi sendiri, mengulang dan mengingat, mencari bantuan sosial, dan mereview catatan. Sejalan dengan pendapat tersebut, Rochester Institute of Technology (Sumarmo, 2013) juga mengidentifikasi beberapa karakteristik dari kemandirian belajar, yaitu: memilih tujuan belajar, memandang kesulitan sebagai tantangan, memilih dan menggunakan sumber yang tersedia, bekerjasama dengan individu lain, membangun makna, memahami pencapaian keberhasilan tidak cukup hanya dengan usaha dan kemampuan saja namun harus disertai dengan kontrol diri.

Berdasarkan penjelasan tentang kemandirian belajar yang telah dikemukakan di atas, kemandirian belajar siswa dalam penelitian ini dikembangkan berdasarkan 9 indikator yaitu: (1) inisiatif dan motivasi belajar intrinsik; (2) kebiasaan mendiagnosa kebutuhan belajar; (3) menetapkan 
tujuan/target belajar; (4) memonitor, mengatur, dan mengontrol belajar; (5) memandang kesulitan sebagai tantangan; (6) memanfaatkan dan mencari sumber yang relevan; (7) memilih dan menerapkan strategi belajar; (8) mengevaluasi proses dan hasil belajar; (9) konsep diri/kemampuan diri.

\section{b. Pembelajaran Kooperatif dengan aktivitas quick on the draw}

Pembelajaran kooperatif sering dikenal dengan pembelajaran kelompok karena lebih mengutamakan adanya kelompok-kelompok. Menurut Wahyudin (2008) belajar kooperatif adalah pengalaman yang dapat menanamkan kesadaran dalam diri siswa bahwa mereka bersatu dalam suatu upaya bersama, bahwa mereka akan berhasil atau gagal sebagai sebuah tim, dan masing-masing bertanggung jawab untuk mempelajari muatan pelajaran. Sementara itu Hosnan (2014) menjelaskan bahwa pembelajaran kooperatif dapat diartikan sebagai suatu sikap atau perilaku bersama dalam bekerja atau membantu di antara sesama dalam struktur kerjasama yang teratur dalam kelompok, dimana keberhasilan kerja sangat dipengaruhi oleh keterlibatan setiap anggota kelompok itu sendiri.

Berdasarkan pendapat-pendapat di atas dapat disimpulkan bahwa pembelajaran kooperatif merupakan suatu pembelajaran dengan cara siswa dikelompokkan ke dalam kelompok-kelompok kecil, kemudian diberikan tugastugas terstruktur yang menekankan adanya kerjasama pada setiap anggota kelompok untuk menyelesaikan permasalahan dalam rangka mencapai tujuan pembelajaran.

Quick on the draw merupakan sebuah aktivitas untuk melakukan kerja tim dan kecepatan. Aktivitas ini merupakan pacuan antar kelompok dan tidak terlalu rumit. Tujuannya adalah menjadi kelompok pertama yang mampu menyelesaikan satu set pertanyaan. Aktivitas quick on the draw ini lebih menekankan kerja kelompok, semakin efisien kerja kelompok, semakin cepat kemajuannya. Kegiatan ini membantu siswa untuk membiasakan diri belajar pada sumber, bukan pada guru. Quick on the draw akan memberikan pengalaman mengenai keterampilan membaca dan menulis, yang didorong oleh kecepatan beraktivitas, ditambah belajar mandiri, membaca pertanyaan dengan hati-hati, menjawab pertanyaan dengan tepat, serta membedakan antara materi yang penting dan tidak penting. Adapun dalam pelaksanaannya, aktivitas quick on the draw ini dapat melatih kemampuan berpikir siswa, kemandirian, saling ketergantungan, dan terasa menyenangkan (Ginnis, 2008).

Pembelajaran yang dilaksanakan dalam penelitian ini adalah pembelajaran matematika secara kooperatif dengan aktivitas quick on the draw. Aktivitas quick on the draw ini disisipkan pada salah satu tahapan pembelajaran kooperatif, yaitu pada fase keempat (membimbing kelompok bekerja dan belajar). Penyisipan quick on the draw pada fase keempat dikarenakan aktivitas ini merupakan suatu kegiatan kelompok yang dalam pelaksanaannya siswa masih mendapatkan bimbingan dan arahan dari guru. Oleh karena itu, aktivitas ini akan sejalan dengan fase keempat pembelajaran kooperatif yang memang dalam kegiatan berkelompoknya masih perlu mendapat arahan dan bimbingan dari guru.

Langkah-langkah pembelajaran pada penelitian ini yaitu: (a) Fase 1, menyampaikan tujuan pembelajaran, memotivasi siswa, dan mengecek pengetahuan awal siswa; (b) Fase 2, menyajikan informasi; (c) Fase 3, mengorganisasikan siswa ke dalam kelompok-kelompok belajar; (d) Fase 4, 
membimbing kelompok dan aktivitas quick on the draw; (e) Fase 5, evaluasi; dan (f) Fase 6, memberikan penghargaan.

\section{METODE PENELITIAN}

Penelitian ini merupakan penelitian kuasi eksperimen yang dilaksanakan pada dua kelas yaitu kelas eksperimen dan kelas kontrol. Hal yang membedakan adalah perlakuan (treatment) yang diberikan. Perlakuan yang diberikan pada kelas eksperimen adalah pembelajaran kooperatif dengan aktivitas quick on the draw dan kelas kontrol menggunakan pembelajaran biasa.

Desain penelitiannya adalah desain perbandingan kelompok statik. Adapun desain penelitiannya bila digambarkan adalah sebagai berikut (Ruseffendi, 2010).<smiles>[Y][Co]=O</smiles>

Keterangan:

$\mathrm{X}=$ perlakuan pembelajaran berupa pembelajaran kooperatif dengan aktivitas quick on the draw

$\mathrm{O}=$ postes kemandirian belajar matematika siswa

---- $=$ subjek tidak dipilih secara acak

Populasi dalam penelitian ini adalah seluruh siswa kelas VIII di salah satu SMP Negeri di Kabupaten Tangerang. Pengambilan sampel dalam penelitian ini melalui teknik pusposif sampling yang bersifat subyektif dimana pemilihan sampel didasarkan pada pertimbangan peneliti dan guru yang bersangkutan. Penelitian ini melibatkan variabel bebas dan variabel terikat. Variabel bebasnya adalah pembelajaran kooperatif dengan aktivitas quick on the draw serta variabel terikatnya adalah kemandirian belajar matematika siswa.

Instrumen yang digunakan dalam penelitian ini adalah angket skala kemandirian belajar yang diberikan pada kelas eksperimen dan kelas kontrol di akhir pembelajaran. Pernyataan pada lembar angket tersebut bertujuan untuk mengetahui kemandirian belajar siswaketika proses pembelajaran matematika. Angket ini disusun sesuai dengan indikator yang digunakan dalam penelitian ini.

Angket sikap ini mengacu pada bentuk skala Likert yaitu sangat setuju (SS), setuju (S), tidak setuju (TS) dan sangat tidak setuju (STS) dengan tidak terdapat pilihan netral. Setiap pilihan jawabannya diberi skor minimal 1 dan maksimal 4. Siswa yang menjawab pernyataan positif dengan jawaban sangat setuju (SS) diberi nilai 4 dan untuk pilihan jawaban lainnya, yaitu S, TS dan STS berturut-turut berbeda satu. Sebaliknya untuk pernyataan negatif yang jawabannya sangat tidak setuju (STS) diberi nilai 4 dan untuk pilihan lainnya, yaitu TS, S, dan SS berturut-turut berbeda satu. Berikut ini adalah pedoman penskoran untuk angket kemandirian belajar siswa.

Tabel 1. Pedoman Penskoran Skala Kemandirian Belajar Matematika Siswa

\begin{tabular}{ccccc}
\hline \multirow{2}{*}{ Jenis Pernyataan } & \multicolumn{4}{c}{ Skor } \\
& SS & S & TS & STS \\
\hline Positif & 4 & 3 & 2 & 1 \\
Negatif & 1 & 2 & 3 & 4 \\
\hline
\end{tabular}

Angket skala kemandirian belajar ini sebelum digunakan terlebih dahulu dilakukan validasi teoritik dan empirik. Berdasarkan hasil uji coba instrument 
angket kemandirian belajar, ada beberapa item yang tidak valid sehingga perlu diperbaiki dan ada pula yang dibuang. Oleh karena itu dalam penelitian ini instrument kemandirian belajar yang digunakan terdiri 30 pernyataan, yaitu 22 pernyataan positif dan 8 pernyataan negatif. Jawaban angket siswa ditransformasikan dari data kualitatif ke data kuantitatif dengan menggunakan bantuan program Method of Succesive Interval (MSI). Selanjutnya data tersebut diuji statistik dengan menggunakan program SPSS 17.0 for Windows.

\section{HASIL DAN PEMBAHASAN}

\section{Hasil Penelitian}

Angket skala kemandirian belajar diberikan kepada siswa di kelas eksperimen dan kelas kontrol setelah mendapat pembelajaran. Hasil angket digunakan untuk melihat apakah terdapat perbedaan kemandirian belajar siswa pada kedua kelas yang dijadikan sampel penelitian. Deskripsi data angket kemandirian belajar matematika siswa pada kedua kelas disajikan pada table berikut ini.

Tabel 2. Deskripsi Data Skala Kemandirian Belajar Matematika Siswa

\begin{tabular}{cccccc}
\hline Kelas & N & Min. & Max. & $\overline{\boldsymbol{x}}$ & SD \\
\hline Eksperimen & 32 & 72,97 & 116,81 & 96,57 & 12,19 \\
Kontrol & 31 & $\begin{array}{c}64,08 \\
\text { Skor Ideal }=124,86\end{array}$ & 84,84 & 12,12 \\
& \multicolumn{5}{c}{} \\
\hline
\end{tabular}

Tabel 2 memperlihatkan bahwa rata-rata skor skala kemandirian belajar matematika siswa kelas eksperimen lebih tinggi daripada siswa kelas kontrol dengan selisih sebesar 11,69. Rata-rata kemandirian belajar siswa kelas eksperimen sebesar 68,28\% dan kelas kontrol sebesar 60,01\% dari skor ideal. Hal ini menunjukkan bahwa aktivitas quick on the draw dalam pembelajaran kooperatif memberikan kontribusi yang cukup baik dalam mengembangkan kemandirian belajar siswa meskipun masih jauh dari skor ideal. Selain itu, apabila dilihat dari standar deviasinya, tingkat penyebaran skor kemandirian belajar kedua kelas hampir sama, artinya data skor kemandirian belajar matematika siswa kelas eksperimen tidak jauh bervariasi dibandingkan kelas kontrol.

Pemaparan data-data yang telah disampaikan di atas hanyalah gambaran umum dari hasil penelitian. Gambaran umum tersebut belum tentu mampu secara kuat untuk diambil kesimpulan dalam penelitian. Oleh karena itu perlu dilakukan analisis lebih lanjut yaitu dengan pengujian secara statistik. Analisis data angket dilakukan dengan bantuan program SPSS 17.0 for Window pada taraf signifikansi 0,05 .

Berdasarkan Tabel 2, terlihat perbedaan rata-rata skor kemandirian belajar matematika siswa pada kedua kelas. Untuk melihat apakah terdapat perbedaan yang signifikan pada skor kemandirian belajar matematika siswa kelas eksperimen dan kelas kontrol, dilakukan uji perbedaan rata-rata. Sebelum dilakukan uji perbedaan rata-rata tersebut, terlebih dahulu dilakukan uji prasyarat yaitu uji normalitas dan uji homogenitas varians.

\section{a. Uji Normalitas}

Uji normalitas skor kemandirian belajar matematika siswa dilakukan untuk 
mengetahui apakah skor kemandirian belajar matematika siswa pada kelas eksperimen dan kelas kontrol berdistribusi normal atau tidak. Pengujian normalitas ini dilakukan menggunakan uji Saphiro Wilk pada taraf signifikansi $\alpha$ $=0,05$ dengan bantuan program SPSS 17.0 for Windows.

Kriteria pengujiannya (Uyanto, 2009) adalah : Jika nilai Sig. $(p$-value $)<\alpha$ $(\alpha=0,05)$, maka Tolak $\mathrm{H}_{0}$; dan Jika nilai Sig. $(p$-value $) \geq \alpha(\alpha=0,05)$, maka Terima $\mathrm{H}_{0}$. Adapun hasil uji normalitas dapat dilihat pada tabel berikut ini.

Tabel 3. Data Hasil Uji Normalitas Skor Kemandirian Belajar Matematika

\begin{tabular}{|c|c|c|c|c|c|}
\hline \multirow{2}{*}{ Kelas } & \multicolumn{3}{|c|}{ Saphiro-Wilk } & \multirow{2}{*}{ Ket. } & \multirow{2}{*}{ Kesimpulan } \\
\hline & Statistic & $d f$ & Sig. & & \\
\hline Eksperimen & 0,967 & 32 & 0,422 & Terima $\mathrm{H}_{0}$ & Berdistribusi normal \\
\hline Kontrol & 0,940 & 31 & 0,085 & Terima $\mathrm{H}_{0}$ & Berdistribusi normal \\
\hline
\end{tabular}

Berdasarkan tabel di atas, terlihat bahwa nilai Sig. skor kemandirian belajar siswa kelas eksperimen dan kontrol $(0,422$ dan 0,085) lebih besar dari taraf signifikansi yang telah ditetapkan $(\alpha=0,05)$, sehingga $\mathrm{H}_{0}$ diterima. Hal ini berarti skor kemandirian belajar siswa kelas eksperimen dan kelas kontrol berasal berdistribusi normal. Dikarenakan kedua kelas berdistribusi normal, maka langkah selanjutnya adalah uji homogenitas varians.

\section{b. Uji Homogenitas Varians}

Pengujian homogenitas varians skor kemandirian belajar matematika menggunakan uji Levene dengan bantuan program SPSS 17 for Windows pada taraf signifikansi $\alpha=0,05$. Kriteria pengujiannya (Uyanto, 2009) adalah : Jika nilai Sig. ( $p$-value $)<\alpha(\alpha=0,05)$, maka Tolak $\mathrm{H}_{0}$; dan Jika nilai Sig. ( $p$-value $) \geq$ $\alpha(\alpha=0,05)$, maka Terima $\mathrm{H}_{0}$. Adapun hasil uji homogenitasnya dapat dilihat pada tabel berikut ini.

Tabel 4. Data Hasil Uji Homogenitas Varians Skor Kemandirian Belajar Matematika Siswa

\begin{tabular}{cccccc}
\hline Levene Statistic & df1 & df2 & Sig. & Ket. & Kesimpulan \\
\hline 0,479 & 1 & 61 & 0,492 & Terima $\mathrm{H}_{0}$ & Varians homogen \\
\hline
\end{tabular}

Tabel di atas menunjukkan bahwa skor kemandirian belajar matematika siswa mempunyai nilai Sig. yang lebih besar dari taraf signifikansi yang ditetapkan $(\alpha=0,05)$ sehingga $\mathrm{H}_{0}$ diterima. Artinya skor kemandirian belajar matematika siswa kelas eksperimen dan kelas kontrol memiliki varians yang homogen.

\section{c. Uji Perbedaan Rata-rata}

Setelah diketahui bahwa data kemandirian belajar matematika siswa memenuhi uji prasyarat normalitas dan homogenitas, langkah selanjutnya adalah uji perbedaan skor kemandirian belajar dengan menggunakan independent sample t-test dengan bantuan program SPSS 17 for Windows. Hipotesis penelitian yang diajukan adalah "Kemandirian belajar matematika siswa yang belajar menggunakan pembelajaran kooperatif dengan aktivitas quick on the draw lebih baik secara signifikan daripada siswa yang memperoleh pembelajaran biasa”. 
Adapun hipotesis statistiknya adalah sebagai berikut.

$$
\begin{aligned}
& H_{0}: \mu_{e} \leq \mu_{k} \\
& H_{1}: \mu_{e}>\mu_{k}
\end{aligned}
$$

Keterangan:

$\mu_{e} \quad$ : Rata-rata skor kemandirian belajar matematika siswa kelas eksperimen

$\mu_{k} \quad$ : Rata-rata skor kemandirian belajar matematika siswa kelas kontrol

Kriteria pengujian yang dipakai (Uyanto, 2009) adalah jika nilai $\frac{1}{2} \operatorname{Sig}(p$ value $)<\alpha(\alpha=0,05)$, maka Tolak $\mathrm{H}_{0}$; dan jika nilai $\frac{1}{2}$ Sig. ( $p$-value $) \geq \alpha(\alpha=0,05)$, maka Terima $\mathrm{H}_{0}$. Berikut ini disajikan hasil perhitungannya.

Tabel 5. Data Hasil Uji Perbedaan Rata-rata Skor Kemandirian Belajar Matematika Siswa

\begin{tabular}{cccccc}
\hline Asumsi Varian & t & Df & $\begin{array}{c}\text { Sig. } \\
(\text { 2-tailed) }\end{array}$ & $\begin{array}{c}\text { Sig. } \\
(\text { 1-tailed })\end{array}$ & Keterangan \\
\hline Homogen & 3,818 & 61 & 0,000 & 0,000 & Tolak $\mathrm{H}_{0}$ \\
\hline
\end{tabular}

Berdasarkan hasil uji perbedaan rata-rata pada Tabel 5 diperoleh nilai Sig.(2-tailled $)=0,000$. Akan tetapi dalam penelitian ini uji perbedaan dua ratarata yang digunakan adalah uji satu pihak, sehingga nilai Sig. (1-tailed) adalah $\frac{1}{2} \times 0,000=0,000$. Nilai ini lebih kecil dari nilai signifikansi yang ditentukan $(\alpha=$ 0,05 ), sehingga $\mathrm{H}_{0}$ ditolak. Artinya, rata-rata skor kemandirian belajar matematika siswa yang belajar menggunakan pembelajaran kooperatif dengan aktivitas quick on the draw lebih baik secara signifikan daripada siswa yang memperoleh pembelajaran biasa. Dengan demikian hipotesis penelitian ini terbukti.

\section{Pembahasan}

Analisis kemandirian belajar dalam penelitian ini bukanlah peningkatan karena untuk ranah afektif sulit mengukur peningkatannya bila hanya dilakukan pembelajaran dalam waktu yang singkat. Pada dasarnya setiap siswa sudah memiliki kemandirian belajar masing-masing sebelum dimulai pembelajaran. Oleh karena itu dalam penelitian ini yang dilihat adalah perbedaan pencapaian kemandirian belajar siswa setelah perlakuan pembelajaran dilakukan pada kedua kelas.

Hasil penelitian menunjukkan bahwa kemandirian belajar matematika siswa yang belajar menggunakan pembelajaran kooperatif dengan aktivitas quick on the draw (kelas eksperimen) lebih baik daripada siswa yang memperoleh pembelajaran biasa (kelas kontrol). Berdasarkan uji statistik secara deskriptif kemandirian belajar matematika pada kedua kelas, diperoleh hal bahwa dari 32 siswa kelas eksperimen rata-rata skor kemandirian belajarnya adalah 96,57 dengan nilai minimum 72,97 dan nilai maksimum 116,81 serta standar deviasi 12,19. Sedangkan pada kelas kontrol, dari 31 siswa rata-rata skor kemandirian belajarnya adalah 84,88 dengan nilai minimum 64,08 dan nilai maksimum 124,86 serta standar deviasinya sebesar 12,12. Secara deskriptif terlihat bahwa rata-rata skor kemandirian belajar siswa kelas eksperimen lebih baik dari kelas kontrol. Hal ini didukung juga berdasarkan statistik uji Independen sample t-test dengan taraf 
signifikansi $\alpha=0,05$ menyimpulkan bahwa kemandirian belajar siswa yang belajar menggunakan pembelajaran kooperatif dengan aktivitas quick on the draw lebih baik secara signifikan daripada siswa yang memperoleh pembelajaran biasa.

Hasil di atas memberikan gambaran bahwa pembelajaran kooperatif dengan aktivitas quick on the draw berpengaruh terhadap kemandirian belajar siswa. Pembelajaran seperti ini lebih berpengaruh karena dalam prosesnya siswa lebih aktif berinteraksi dengan sesama temannya. Siswa dapat secara aktif mencari bahan-bahan sumber yang relevan dengan materi pembelajaran kemudian berbagi pengetahuannya dalam mengerjakan tugas-tugas akademik, sehingga siswa tidak tergantung hanya pada penjelasan dari guru. Hal ini juga sejalan dengan dengan pendapat Ginnis (2008) yang mengungkapkan bahwa aktivitas quick on the draw yang pembelajarannya memang dilakukan secara kelompok dapat memberikan pengalaman kepada siswa tentang keterampilan membaca, ditambah belajar mandiri, dan kecakapan ujian yang lain. Kegiatan ini dapat membantu siswa untuk membiasakan diri belajar pada sumber, bukan guru. Temuan ini juga sesuai dengan hasil penelitian yang dilakukan oleh Sumarni (2014) bahwa kemandirian belajar siswa yang memperoleh pembelajaran secara berkelompok melalui Learning Cycle $5 E$ lebih baik daripada siswa yang memperoleh pembelajaran konvensional.

\section{SIMPULAN DAN SARAN}

Berdasarkan hasil penelitian dan pembahasan dapat disimpulkan bahwa kemandirian belajar matematika siswa yang menggunakan pembelajaran kooperatif lebih baik secara signifikan daripada siswa yang memperoleh pembelajaran biasa. Pembelajaran seperti ini dapat melatih siswa untuk lebih aktif dan dapat menumbuhkan kemandirian siswa sehingga diharapkan dapat membekali siswa untuk kehidupan di masa mendatang. Bagi peneliti yang akan mengembangkan penelitian ini, diharapkan dapat melakukan penelitian pada jenjang yang lebih tinggi seperti tingkat SMA maupun tingkat perguruan tinggi dengan populasi yang lebih luas. Selain itu penelitian ini diharapkan dapat dikembangkan pada aspek afektif matematis lainnya agar siswa semakin semangat dalam belajar matematika.

\section{DAFTAR RUJUKAN}

Darr dan Fisher. (2004). Self Regulated Learning in The Mathematics Class. Makalah pada konferensi NZARE 24-26 November 2004 di Wellington. [online]. Tersedia di https://www.nzcer.org.nz/system/files/13903.pdf [Diakses pada Februari 2019]

Ginnis, P. (2008). Trik dan Taktik Mengajar. Jakarta: PT. Indeks.

Hidayat, E. (2009). Peningkatan Kemampuan Komunikasi Matematik dan Kemandirian Belajar Siswa SMP dengan Menggunakan Pendekatan Matematika Realitik. Tesis Pascasarjana UPI: Tidak Diterbitkan.

Hosnan, M. (2014). Pendekatan Saintifik dan Kontekstual dalam Pembelajaran Abad 21. Bogor: Ghalia Indonesia.

Majid, A. (2014). Implementasi Kurikulum 2013. Bandung: Interes Media.

Permana, Y. (2010). Mengembangkan Kemampuan Pemahaman, Komunikasi, dan Disposisi Matematis Siswa Sekolah Menengah Atas Melalui ModelEliciting Activities. Disertasi Pascasarjana UPI: Tidak Diterbitkan. 
Russeffendi, E.T. (2010). Dasar-Dasar Penelitian Pendidikan \& Bidang NonEksakta Lainnya. Bandung: Tarsito

Sumarmo, U. (2013). Kumpulan Makalah Berpikir dan Disposisi Matematik serta Pembelajarannya. Bandung: Jurdikmat UPI.

Sumarni. (2014). Penerapan Learning Cycle 5e untuk Meningkatan Kemampuan Koneksi Dan Komunikasi Matematis Serta Self-Regulated Learning Matematika Siswa. Bandung: Tesis Pascasarjana UPI: Tidak Diterbitkan

Undang-undang Negara Republik Indonesia Nomor 20 Tahun 2003 tentang Sistem Pendidikan Nasional.

Uyanto, S.S. (2009). Pedoman Analisis Data dengan SPSS. Yogyakarta: Graha Ilmu.

Wahyudin. (2008). Pembelajaran dan Model-model Pembelajaran. Bandung: UPI Press.

Zamnah, L.N. (2012). Meningkatkan Kemampuan Pemecahan Masalah Matematis dan Self-Regulated Learning melalui Pendekatan Problem Centered Learning dengan Hands-on Activity. Tesis Pascasarjana UPI: Tidak Diterbitkan.

Zumbrun, Tadlock, dan Robert. (2011). Encouraging Self-Regulated Learning in the Classroom: a Review of the Literature. Disampaikan pada Metropolitan Educational Research Consortium (MERC), Virginia Commonwealth University, Oktober 2011. [Online]. Tersedia di www.mehritcentre.com/assets/.../Self\%20Regulated\%20Learning.pdf.

[Diakses pada November 2014] 